\title{
Mulheres cariocas e práticas de leitura nos anos de 1920: um estudo documental a partir das revistas Fon- Fon e Jornal das Moças
}

\section{Nathalia Paulino Oliveira}

Bibliotecária pela Universidade Federal do Estado do Rio de Janeiro.Chefe de Biblioteca Setorial na Universidade Veiga de Almeida, campus Cabo Frio.

Fabrício José Nascimento da Silveira

Bibliotecário. Mestre e doutor em Ciência da Informação pelo PPGCI/UFMG. Professor Adjunto I da Escola de Ciência da Informação - ECI/UFMG nas modalidades graduação e pós-graduação

http://dx.doi.org/10.1590/1981-5344/2560

O presente artigo tem por objetivo investigar as práticas de leitura empreendidas pelas mulheres cariocas dos anos de 1920, adotando como objeto de análise duas revistas endereçadas especificamente a esse público, são elas: Fon-Fon e Jornal das Moças. Para tanto, apresenta-se o conjunto de fatores sócio-históricos que impulsionaram o desenvolvimento da imprensa periódica no Brasil e o aparecimento das "revistas femininas" no Rio de Janeiro no período da Belle Époque. Em seguida, e tendo por prerrogativa que tanto a revista Fon-Fon quanto a Jornal das Moças constituem-se em fontes históricas, efetua-se um estudo documental com vistas a identificar as necessidades e os usos da informação que se mostram associados às práticas de leitura das assinantes de ambos os periódicos. Em termos de resultados, além de salientar as dinâmicas de socialização instituídas para e pelo público feminino, o trabalho ressalta como as duas revistas se converteram em ferramentas auxiliares à formação intelectual da mulher carioca na década de 1920 e como as mesmas agiam em favor do lazer, da educação e da disseminação da informação entre suas leitoras.

Palavras-chaves: Práticas de leitura; Revista feminina; Educação feminina; Imprensa periódica; Revista Fon-Fon; Revista Jornal das Moças. 


\title{
Women from Rio and reading practices in the 1920s: a documentary study from the magazines "Fon-Fon" and "Jornal das Moças"
}

\begin{abstract}
This paper aims to investigate the reading practices undertaken by women of Rio de Janeiro in the 1920s, having as object of analysis two magazines specifically addressed to this audience. They are: "Fon-Fon" "Jornal das Moças". It presents the set of socio-historical factors that have driven the development of the periodical press in Brazil and the appearance of "women's magazines" in Rio de Janeiro in the period of the Belle Époque. Then, taking a prerogative that both the Fon-Fon Magazine and Jornal das Moças constitute in historical sources, it is made a desk study in order to identify the needs and the information uses that seems to be associated with the reading practices of the subscribers of both journals. In terms of results, besides emphasizing the socialization dynamics established by and for the female audience, the work points out how the two magazines have become an important tool to the intellectual formation of the woman from Rio de Janeiro in the 1920s and how they acted in favor of leisure, education and dissemination of information among its readers.
\end{abstract}

Keywords: Reading practices; Women's magazine; Female education; Periodical Press ; Magazine Fon-Fon; Magazine; Jornal das Moças Magazine.

Recebido em 19.09.2015 Aceito em 17.04.2016

\section{Introdução}

O conjunto de estudos até aqui empreendidos sobre a historicidade das revistas femininas no Brasil nos aponta para um fato curioso: o conhecimento acerca de tal temática ainda se mostra pouco sistematizado no campo da Biblioteconomia e da Ciência da Informação, principalmente naquilo que se refere ao delineamento das práticas leitoras mobilizadas por esses dispositivos documentais ao longo das primeiras décadas do século XX. Sendo assim, e partindo de tal constatação, o presente artigo consolida-se tendo por referência o seguinte objetivo: investigar, sob os moldes de uma pesquisa documental, as práticas de leitura empreendidas 
pelas mulheres cariocas dos anos de 1920, adotando por empiria duas revistas endereçadas especificamente a esse público, são elas: Fon-Fon e Jornal das Moças.

Para tanto, em termos de encaminhamentos teórico-metodológicos, a primeira parte do texto contextualiza cultural e historicamente os movimentos que propiciaram o surgimento de revistas voltadas especificamente para o público feminino e discute como a imprensa periódica no Rio de Janeiro promoveu, sobretudo a partir da década de 1920, uma democratização do acesso à informação e à leitura para as mulheres. O enfoque recai, pois, no conjunto de transformações que modificaram substancialmente as relações mantidas pelas moças e senhoras da Belle Époque ${ }^{1}$ carioca com 0 universo das práticas informacionais e de leitura e como sua inserção no mundo das letras alterou as possibilidades de participação das mesmas nos distintos domínios da vida social instituídos naquele período.

Posteriormente, e já no plano analítico, discute-se a importância que as revistas destinadas ao "belo sexo" tiveram junto aos processos de popularização da leitura e de democratização do acesso à informação entre as mulheres. Sobrepondo-se às suas funções de veículo de entretenimento, tais periódicos insurgem como dispositivos informacionais preocupados em atender às necessidades intelectuais específicas do público feminino, razão pela qual, ao lado de textos literários - trechos de romances, contos e poesias -, passam a figurar em suas páginas informes e relatos destinados a manter as leitoras atualizadas sobre diversos temas de seu interesse, tais como: economia doméstica, moda, práticas de higiene, trabalhos manuais, espetáculos e eventos culturais.

Características que também marcam os dois periódicos eleitos como objetos analíticos deste estudo, são eles: a revista Fon-Fon e a Jornal das Moças. Escolha que levou em consideração o fato de tais revistas serem avaliadas como exemplos representativos no âmbito da história da imprensa feminina brasileira, uma vez que são publicações pioneiras nesse segmento e por terem servido de modelo editorial para suas sucessoras. Outro critério que influenciou nossa escola liga-se ao "tempo de vida" das duas publicações, posto que tanto a Jornal das Moças quanto a Fon-Fon mantiveram-se em circulação por mais de 30 anos, abrangendo diferentes e importantes períodos da história nacional.

Com relação à delimitação do marco temporal - os anos de 1920 faz-se necessário esclarecer que o mesmo foi definido tendo-se por referência 3 grandes fatores históricos: a década de 1920 é considerada o período áureo da história do Rio de Janeiro, sobretudo em função das reformas urbanas levadas a cabo pelo prefeito Pereira Passos nos anos iniciais do século XX. Outro fator importante para a delimitação do período

\footnotetext{
${ }^{1}$ Belle Époque é o termo utilizado após a I Guerra Mundial para definir o período de cultura cosmopolita na história da Europa (entre 1871 e 1914). A expressão também designa o clima intelectual e artístico vivido pela França no período em questão, em especial pela cidade de Paris. No Rio de Janeiro, a Belle Époque foi o período compreendido entre o fim do século XIX e as duas primeiras décadas do século XX, denotando um período de grande modernização urbana e do pensamento social, tomando como exemplo a cultura, a arquitetura art-nouveau, a moda e os hábitos de vida parisienses. Para maiores esclarecimentos sobre o tema, ver: ORTIZ, Renato. Cultura e modernidade: a França no século XIX. São Paulo: Brasiliense, 1991.
} 
foi a Semana de Arte Moderna de 1922, que marcou o início do modernismo no Brasil. Por último, há a crise econômica de 1929 que, apesar de ter se iniciado nos Estados Unidos, repercutiu também na economia brasileira, afetando decisivamente as diretrizes políticas, culturais e sociais que aqui vigoravam, inclusive àquelas ligadas ao universo feminino e das revistas formatadas para esse público.

Em virtude da impossibilidade de se analisar a totalidade dos exemplares publicados de cada revista, procuramos extrair uma amostra significativa dos números lançados na década de 1920. Ao todo, vieram à luz entre os anos de 1920 e 1929², 498 edições do Jornal das Moças e 515 números de Fon-Fon. Operacionalmente, a amostra foi estruturada mediante a escolha de cinco exemplares por ano, contemplando o primeiro e o segundo semestre de cada ano, sendo três edições do primeiro semestre e dois do segundo, invertendo-se no ano subsequente, conforme disposto no quadro abaixo. Tal medida pretendeu alçar um olhar panorâmico sobre as publicações ao longo de cada ano, com vistas a identificar possíveis mudanças ou permanências tanto no formato quanto no conteúdo das edições.

Quadro 1 - Exemplares selecionados das respectivas revistas por mês e ano de publicação

\begin{tabular}{|c|c|c|c|c|c|c|c|c|c|c|}
\hline Ano & \multicolumn{5}{|c|}{ Jornal das Moças } & \multicolumn{5}{|c|}{ Fon-Fon } \\
\hline 1920 & Jan. & Fev. & Mar. & Jul. & Out. & Jan. & Fev. & Mar. & Jul. & Out. \\
\hline 1921 & Abr. & Mai. & Ago. & Set. & Dez. & Abr. & Mai. & Ago. & Set. & Dez. \\
\hline 1922 & Jan. & Mar. & Jun. & Out. & Nov & Jan. & Mar. & Jun. & Out. & Nov \\
\hline 1923 & Fev. & Abr. & Jul. & Set. & Dez. & Fev. & Abr. & Jul. & Set. & Dez. \\
\hline 1924 & Jan. & Fev. & Mar. & Nov. & Dez. & Jan. & Fev. & Mar. & Nov. & Dez. \\
\hline 1925 & Jan. & Fev. & Abr. & Ago. & Set. & Jan. & Fev. & Abr. & Ago. & Set. \\
\hline 1926 & Abr. & Mai. & Jun. & Nov. & Dez. & Abr. & Mai. & Jun. & Nov. & Dez. \\
\hline 1927 & Jan. & Fev. & Ago. & Set. & Out. & Jan. & Fev. & Ago. & Set. & Out. \\
\hline 1928 & Mar. & Mai. & Jun. & Jul. & Out & Mar. & Mai. & Jun. & Jul. & Out \\
\hline 1929 & Mar. & Jun. & Ago. & Set. & Dez. & Mar. & Jun. & Ago. & Set. & Dez. \\
\hline
\end{tabular}

Fonte: Dados da pesquisa.

Além disso, efetivou-se pesquisas em censos e anuários estatísticos da época visando-se reconstituir a situação sócio-demográfica e cultural do Rio de Janeiro no período aqui abordado. Conferiu-se, assim, especial atenção aos índices de alfabetização da população carioca e aos dados que indicavam a presença de mulheres em instituições de ensino (secundário, profissionalizante e superior) e em postos de trabalho. Estratégia que nos permitiu melhor delinear o perfil do público previsto pelas revistas em questão. Delineamento que também levou em consideração os estudos de Araújo (1995) sobre identidade cultural carioca e sobre o papel social da mulher no período da República Velha.

\footnotetext{
${ }^{2}$ Para a constituição da amostra, o estudo empírico recorreu às coleções de periódicos históricos da Fundação Casa de Rui Barbosa e da Biblioteca Nacional, instituições às quais manifestamos nossos agradecimentos.
} 
A partir dessas disposições, as análises empreendidas se mostraram capazes de desvelar os modos de interação estabelecidos entre as revistas Fon-Fon e Jornal das Moças com suas leitoras e de que maneira os dois periódicos redefiniram as dinâmicas de socialização instituídas para e pelo público feminino no contexto carioca da década de 1920. Para além disso, tornaram visíveis que as práticas de leitura agenciadas tanto pela Fon-Fon quanto pela Jornal das Moças tinham como principal finalidade expandir as atividades de lazer e ampliar os índices de instrução de um contingente populacional formado, no geral, por moças e senhoras pertencentes às elites carioca e nacional.

De acordo com essas proposições, três questões importantes devem ser aqui levantadas: como surgem e quais as características das revistas voltadas para o "belo sexo"? Que condições sócio-históricas conferem notoriedade a esse segmento da imprensa periódica no contexto da sociedade carioca das primeiras décadas do século XX? A seção que se segue propõe-se a clarear tais indagações.

\section{0 "belo sexo" também lê: as revistas femininas e sua historicidade}

Desde seu surgimento, a modalidade midiática definida como "revista" já carregava em si o conceito de variedades, uma vez que abordava em cada edição múltiplos assuntos, ainda que sobre uma mesma temática. Conforme exposto na seção anterior, não se constitui como objetivo deste trabalho compor um histórico detalhado sobre a origem das revistas, porém, para sua compreensão geral, faz-se necessário contextualizarmos quando e onde surgiram suas primeiras edições, e que fatores impulsionaram o desenvolvimento dos periódicos femininos, tanto a nível internacional quanto nacional.

Desta feita, olhando retrospectivamente, a literatura especializada da área nos aponta que a primeira revista de que se tem registro foi publicada em Hamburgo, na Alemanha, no ano de 1663. Criado pelo teólogo Johann Rist, o periódico era composto basicamente por uma sequência de artigos sobre um mesmo assunto, reunidos sob o título de Edificantes Discussões Mensais ${ }^{3}$, tendo circulado até o ano de 1668. Marília Scalzo (2003) aponta que essa publicação possuía características semelhantes às de um livro, entretanto pode ser considerada como uma revista porque traz em seu conteúdo uma série de artigos sobre um mesmo assunto e também por ser destinada a um público específico, neste caso, teólogos e leitores abastados de Hamburgo. Contando com grande aceitação e angariando certa popularidade, a revista foi copiada em outros países da Europa. Em 1665 surgem a francesa Jornal dos Sábios e a inglesa Transações Filosóficas. Posteriormente, em 1668, surge, na Itália, o Jornal dos Literatos.

${ }^{3}$ O título original da revista em alemão é ErbaulicheMonaths-Unterredugen, traduzido como Edificantes Discussões Mensais 
Projetando uma nova tendência, institucionalizou-se na França, no ano de 1672, a ideia de se abordar diferentes temas em uma só revista. Tem início, assim, a publicação multitemática Mercúrio Galante, que apresentava em suas páginas poesia, notícias curtas, crônicas sobre a Corte e anedotas. Contudo, o primeiro periódico a possuir feições semelhantes às edições atuais veio à luz em Londres, no ano de 1731, sob o título Revista do Cavalheiro ${ }^{4}$. É nessa data que se registra o termo magazine, conceito que passou a referenciar o nome revista tanto em inglês quanto em francês.

Naquilo que se refere ao periódico feminino, segundo as indicações de Dulcília Buitoni (2009), o primeiro exemplar veio a público trinta anos após esses experimentos iniciais. De acordo com a autora, a revista precursora foi a Mercúrio das Senhoras ${ }^{5}$, editada na Grã-Bretanha em fevereiro de 1693. Nela já é possível detectar a presença do consultório sentimental, uma das marcas registradas deste tipo de publicação. Para Buitoni (2009), os seguintes fatores corroboraram, sobremaneira, para o surgimento das revistas femininas:

[...] Provavelmente o surgimento de jornais ou revistas femininas estava relacionado com a ampliação dos papéis femininos tradicionais, circunscritos até então ao lar ou ao convento. E também com a evolução do capitalismo, que implicava novas necessidades a serem satisfeitas. (BUITONI, 2009, p. 29)

Por sua vez, Scalzo (2003) relembra a importância do contexto em que as revistas começaram a ter sua estrutura definida e a ganharem espaço, não apenas na Europa, mas também nos Estados Unidos. Nas palavras da autora:

[...] Ao longo do século XIX, a revista ganhou espaço, virou e ditou moda. Principalmente na Europa e também nos Estados Unidos. Com o aumento dos índices de escolarização, havia uma população alfabetizada que queria ler e se instruir, mas não se interessava pela profundidade dos livros, ainda visto como pouco acessíveis. (SCALZO, 2003, p. 20).

Observações que não devem ser desconsideradas, uma vez que, assim como provocaria mudanças no âmbito cultural e social, a modernidade advinda da primeira revolução industrial começou a influir nos meios de produção e circulação de materiais impressos. A partir desse momento há um grande avanço técnico nas gráficas, o que possibilitou um aprimoramento das publicações que passaram a ter maior tiragem e qualidade superior, também marcas registradas da revista. Com o aumento da tiragem de exemplares, um público maior foi alcançado o que, consequentemente, atraiu anunciantes de serviços e produtos. Os

\footnotetext{
${ }^{4}$ Título original The Gentleman's Magazine.

${ }^{5}$ The Lady's Mercury era o título original em inglês.
} 
anúncios tiveram um papel importantíssimo na difusão das revistas, já que com a ajuda financeira dos anunciantes as publicações puderam reduzir seus preços e atrair mais leitores.

Outro fator que pode servir como justificativa para a popularização das revistas consiste no fato desses dispositivos tratarem de temas mais leves, seguindo um viés mais educativo e cultural. Segundo Buitoni (2009, p. 30), as revistas da segunda metade do século XVIII não se distanciaram muito desse princípio editorial.

Posteriormente surge nos Estados Unidos o American Magazine, um dos primeiros periódicos dedicado exclusivamente ao público feminino, todavia, a revista que alcançou maior inserção entre as leitoras desse período foi a Ladies' Magazine, de 1828. A revista tinha a peculiaridade de ser feita por uma mulher ${ }^{6}$, Sara Hale, uma ativista que defendia os direitos de suas companheiras de sexo. Ainda de acordo com Buitoni (2009, p. 30), Sara Hale foi uma ferrenha defensora do acesso à educação por parte das mulheres, posto considerar esse o mais essencial de todos os direitos. A filosofia editorial de Sara se baseava, pois, em três pilares: entretenimento, esclarecimento e prestação de serviços.

A partir de tais premissas, Sara Hale pretendia formatar uma publicação que quebrasse com 0 padrão das revistas femininas estabelecido até então, a saber: edições com temas mundanos, porém sem abordar assuntos mais pesados como ciências e política, que eram peculiares ao universo de socialização masculina. Não por acaso, a regra geral dizia que as publicações destinadas às mulheres deveriam apresentar em suas páginas temas alheios à realidade dos fatos e acontecimentos sociais e políticos, aproximando-se, inclusive, do mesmo formato tipográfico dos livros em circulação até o ano de 1842.

Quebrando com essa tradição, surge em Londres uma publicação revolucionária, que ainda nos dias atuais serve como modelo para os periódicos femininos, trata-se da Illustrated London News, uma publicação de 16 páginas de texto e 32 de gravuras, que reproduziam os acontecimentos da época na forma de desenho (SCALZO, 2003).

Elementos históricos que nos permitem apontar, assim como o fez Dulcília Buitoni (1990, p. 7), que o sexo do público é o principal elemento definidor da natureza da revista, sendo assim, a noção de imprensa feminina desenvolve-se como um conceito sexuado. É a mulher quem compõe a caracterização da imprensa feminina, não só como receptora, mas também como produtora. Percepção que nos incita, para melhor compreendermos a natureza dos nossos objetos de análise, a formularmos aqui mais uma questão: como definir a natureza de uma revista feminina?

Entender a especificidade de tais veículos comunicacionais e apreendermos sua importância sócio-cultural implica distendermos o conceito corrente segundo o qual as revistas femininas são um tipo de periódico dedicado às mulheres, estando, por isso, ligado ao jornalismo de

\footnotetext{
${ }^{6}$ Até aquele momento a maioria dos periódicos dedicados ao público feminino era escrita e editada por homens.
} 
futilidade, cujo objetivo central seria entreter com lazer e frivolidades moças e senhoras das mais distintas idades e posições sociais, priorizando, para tanto, conteúdos ligados à moda, culinária, fofocas ou conselhos práticos do cotidiano. Indo além disso, conforme nos lembra Nahes (2007, p. 72), os periódicos femininos possuem uma função ideológica, seja para disseminar determinado posicionamento político da empresa que o mesmo representa, seja para dar voz às ideologias de um Estado regulador. Portanto, essa acepção corrente confere às revistas femininas um lugar demarcado no âmbito da esfera comunicacional: oferecer em suas páginas padrões idealizados de comportamento para determinados grupos de leitoras/consumidoras, servindo, assim, de veículo para novas ideias, hábitos, costumes e práticas de engajamento político que propõem modelos de formação da mulher-leitora no decorrer dos anos.

Não por acaso, diferente do conceito de imprensa geral, onde o elemento definidor é a atualidade das notícias, o debate, a análise dos fatos, a objetividade, a imprensa voltada ao "belo sexo" define-se como jornalismo de amenidades e entretenimento, muitas vezes ligado à regra principal de oferecer modelos de consumo ou comportamento. É isso que nos aponta Bonvoison e Maignien (1986, p. 5, tradução nossa), ao afirmarem que "uma das principais funções das revistas femininas é fornecer modelos culturais e estilos de vida, porque incentiva seus leitores a escolher bens de consumo moldando suas necessidades."7.

Por outra via, naquilo que concerne à natureza de seu público, o periódico feminino pode ser inserido na categoria de jornalismo especializado, opondo-se à imprensa geral, já que esta, segundo Nahes (2007, p. 76), visa ao conjunto do público sem grandes distinções de sexo, classe ou atividade.

Complementando essas duas proposições, Roland E. Wolseley ${ }^{8}$ (1972 apud NAHES, 2007, p. 77), ressalta que as revistas podem ser separadas em dois grupos: para consumidores (ou de interesse geral), e especializada. Entretanto, Buitoni (1990) mostra-se contrária a esta categorização da imprensa feminina como especializada e argumenta que:

Imprensa de interesse geral, imprensa de público especializado, imprensa de assunto especializado, nenhuma dessas definições é adequada ao tipo de mídia que ora analisamos. Interesse geral não seria, embora homens também sejam leitores de veículos femininos. Mulheres não constituem um público especializado; além disso, não dá para falar em especialização de assunto, porque a gama possível de matérias é muito grande. (BUITONI, 1990, p. 15).

\footnotetext{
${ }^{7}$ L'une des fonctions principales de la presse féminine est de proposer des modeles culturels et des modes de vie parce qu'elle incite ses lectrices à choisir des biens de consommations et façonne ainsi leurs besoins.

${ }^{8}$ WOLSELEY, Roland Edgar. Understanding magazines. Ames: Iowa State University Press, 1972.
} 
Inserindo uma voz a mais nesse debate, indicamos que Evelyne Sullerot $^{9}$ (1963 apud NAHES, 2007, p. 79), classifica como periódico feminino todos quantos se proclamam destinados às mulheres, sendo concebidos com o objetivo de alcançar esse nicho comercial específico.

Posicionando-nos nessa contenda, adotamos por critério que imprensa feminina define o conjunto de publicações pensado e dirigido às mulheres, caso em que se enquadram nossos objetos de análise, as revistas Fon-Fon e Jornal das Moças.

Definido o conceito e apresentado o panorama histórico a partir do qual as revistas femininas se desenvolveram, cabe-nos agora descrever como essa modalidade de impresso chega em terras brasileiras e quais fatores conferiram-lhes certo grau de popularidade entre as leitoras cariocas do final do século XIX e aquelas que viveram nas décadas iniciais de 1900.

Para tanto, tomamos mais uma vez por referência estudos desenvolvidos no campo da historiografia do impresso, os quais referendam que, no Brasil, a circulação de periódicos destinados ao público feminino só começará a ser notada após a primeira década do século XIX. Atraso que tem como principal justificativa a ausência de uma imprensa oficial até a chegada da Corte Portuguesa em terras coloniais. Nesses termos, conforme afirma Bessone (2005), o surgimento da imprensa feminina no país dá-se como reflexo de profundas mudanças vividas pela sociedade, sobretudo aquele que se constituiu ao redor da estrutura gerencial implementada a partir da vinda da Família Real para as terras brasileiras. De fato, com a chegada da família real ao Brasil, as áreas urbanas começam a serem transformadas, distanciando-se cada vez mais dos padrões provincianos até então em evidência. Surgem ferrovias, novos portos para atender a navios de importação e exportação, entre outras demandas que visavam facilitar a vida do contingente populacional que emigrou junto com a corte.

Razão pela qual, para a maior parte do contingente populacional da antiga colônia, a Corte passou a ser modelo de como se proceder e como se vestir. Com isso, tendências da moda européia eram copiadas pelas mulheres brasileiras, principalmente por aquelas que viviam na cidade do Rio de Janeiro. Contexto que marca o início da extraordinária jornada dos periódicos femininos em território nacional.

Jornada que tem como precursor O Espelho Diamantino, uma publicação quinzenal lançada na nova capital do Império em 1827, tendo circulado por 14 edições. Conforme consta no próprio subtítulo da revista, tratava-se de um "periódico de política, literatura, belas artes, teatro e moda dedicado às senhoras brasileiras", razão pela qual trazia em seu conteúdo textos leves sobre temas mundanos, trechos de romances estrangeiros, críticas de literatura, música, artes e dicas de moda. Segundo Scalzo (2003, p. 28), O Espelho Diamantino possuía cunho didático e se propunha a educar as mulheres com vistas a deixá-las "à altura da civilização e dos seus progressos". Todavia, como acontecera

\footnotetext{
${ }^{9}$ SULLEROT, Evelyne. La presse féminine. Paris: Colin, 1963.
} 
com outras publicações da época, a revista teve curta duração devido à falta de assinantes, subscritores e anunciantes.

Contemporâneo ao Espelho Diamantino, a revista Correio das Moças, editado pelos irmãos Laemmert, alcançou maior sucesso de público, tendo circulado entre os anos de 1838 a 1841 . Publicado aos sábados, trazia em suas páginas artigos sobre moda, literatura, bailes e teatro, entremeados por ilustrações pintadas à mão de figurinos vindos da Europa. Posteriormente, em 1843, veio a público O Espelho Fluminense, periódico que, além dos tradicionais cadernos de moda e literatura, entretia as assinantes com anedotas e charadas.

Embora se mostrassem efervescentes no contexto da corte imperial, as revistas femininas também se disseminaram pelas demais províncias do país. Como título importante podemos citar o Espelho das Brazileiras, lançado em 1831 no Recife. Com duas edições semanais, a publicação enfocava assuntos ligados à moda, à literatura e também a variedades. Conforme noticiado no Diário Pernambucano dias antes do lançamento da revista, o Espelho das Brazileiras pretendia:

Contribuir para a instrução de suas compatriotas, espera (sic) que as pessoas sensatas, longe de admitirem as objeções fúteis dos inimigos da civilização, auxiliarão seus esforços, promovendo no seio de suas famílias a leitura destas folhas, cujo único fim é oferecer às senhoras exemplares capazes de desenvolver seus talentos e lhes inspirar o amor de seus deveres. (DIÁRIO DE PERNAMBUCO, 1831, n. 17, p. 69).

Sendo assim, e por contar com um cenário político e cultural favorável, uma vez que a chegada da Corte portuguesa ao país provocou profundas transformações sociais, era comum o surgimento de novos títulos toda semana, mesmo que a maioria deles não ultrapassassem 5 ou 6 números, tendo algumas revistas se extinguido em sua segunda ou terceira edição. Todavia, em função dos avanços alcançados pela indústria gráfica nacional, a edição desses periódicos tornou-se mais apurada, tendo muitos deles incorporados em suas páginas belas ilustrações. Com isso, já no começo da década de 1850, torna-se possível observar revistas com um período de vida maior, algumas delas circulando até o início do século $X X$.

Segundo Buitoni (2009, p. 37), os títulos a seguir são exemplos de revistas femininas publicadas no Rio de Janeiro que seguiram essa nova tendência: Jornal das Senhoras (1852), que deixa de ser publicado em 1855; O Jornal das Famílias (1863), que teve como colaborador Machado de Assis; $O$ Sexo Feminino (1875-1877), periódico que possuía a particularidade de ter uma mulher como redatora e proprietária Francisca Senhorinha da Mota Diniz - e que ficou conhecido como uma revista defensora da emancipação de suas leitoras. Nesse conjunto, merece ser inserido, ainda, a revista Estação (1879), que, apesar de ser apresentada como um jornal ilustrado para a família, era basicamente um 
periódico de moda e de bordados, no qual os moldes eram entremeados por textos de Machados de Assis. Tendo circulado até 1904, foi nele que o já renomado escritor publicou Quincas Borba ${ }^{10}$.

Embora apresentada de forma panorâmica, a historicidade das primeiras revistas femininas que circularam em terras brasileiras já aponta para uma tendência seguida por aquelas que alcançaram notoriedade entre os anos finais do século XIX e as primeiras décadas dos anos de 1900, qual seja: constituírem em um veículo de disseminação da informação e de modelos de comportamentos a serem seguidos por moças e senhoras da "boa sociedade" carioca. Característica que se acentua sobremaneira no contexto da Belle Époque, momento no qual a imprensa periódica modifica radicalmente a paisagem comunicacional e informacional da capital da República. Com isso, torna-se possível apontarmos que:

Ao contrário dos segmentos leitores que se inauguraram com a República - do leitor de esporte ao público infantil -, a mulher leitora, desde o Império, fora presença assídua no contexto do impresso. Certo que em número limitado e circunscrito a grupos sociais elevados mas, confirmando a leitura como prática feminina recorrente, interessada efetiva naquela produção, sua consumidora em potencial. Entre o consumo e a produção, a mudança de lugar foi rápida. De leitora de folhetins e/ou romances, editados in $8^{\circ}$, formato apropriado para as "diáfanas mãos femininas", passaram respectivamente a colaboradoras e produtoras de revistas. 0 exercício das letras, em princípio condenado pela carga de iniciativa e questionamentos que comportava, foi tolerado e até consentido; mais ainda quando reiterava o tradicional papel feminino de mãe-esposa-rainha do lar. (MARTINS, 2008, p. 371-372, grifos do autor).

De fato, as revistas proporcionaram novos padrões de interação da população com as dinâmicas de produção, circulação e acesso à informação, uma vez que apresentavam em suas páginas um discurso ágil, correlacionado com ilustrações e outras imagens do cotidiano, estratégias que se instituíram como um convite sedutor à leitura e que fizeram a fama de muitos periódicos em fase de implementação e consolidação. Alguns deles chegaram, inclusive, a impactar no modo como certos públicos, especialmente o feminino, exercitavam suas práticas de leitura. Eis o que demonstraremos a seguir através de um estudo documental das revistas Jornal das Moças e Fon-Fon, cujos percursos históricos apresentamos na próxima seção.

\footnotetext{
${ }^{10}$ Machado de Assis inicia a publicação de Quincas Borba na edição de 15 de junho de 1886 e termina no número lançado em 15 de setembro de 1891.
} 


\section{A cada leitora, um magazine: práticas de leitura mobilizadas pelas revistas Fon-Fon e Jornal das moças no Rio de Janeiro da década de 1920}

Os anos iniciais de 1900 determinaram uma guinada significativa no panorama geral da imprensa brasileira. Segundo as análises de Nelson Werneck Sodré (1999), isso se deu porque os sistemas de produção de impressos, respondendo aos anseios de uma sociedade capitalista, alcançaram o ápice de seu desenvolvimento, tornando-se uma "grande empresa". Fruto desse contexto, os periódicos nacionais relativizaram sua função de agentes mobilizadores de ideias e críticas sociais, para se converterem em dispositivos de entretenimento e alienação ideológica. Com isso, as revistas destinadas ao "belo sexo" não sustentavam mais a intenção de despertarem em suas leitoras o interesse por temas ditos "sérios" como cultura, ciências ou economia, mas, antes, oferecer um conteúdo "leve", desprovido de preocupações políticas.

Sendo assim, mesmo inscritas em uma realidade que favorecia a abertura de determinados espaços sociais às mulheres, as revistas a elas endereçadas estavam carregadas de ideologias disciplinadoras, cujos conteúdos limitavam o acesso a certas informações e até mesmo a produtos considerados "úteis" e circunscritos ao universo feminino.

Condição que, por sua vez, não nos impede de apreender certos avanços ensejados por tais modalidades de veículos comunicacionais/informacionais. Com 0 alvorecer do século XX os periódicos, que até então eram tidos como um complemento empobrecido dos livros - veiculando a informação de forma rápida e destituída de refinamento literário -, passaram a assumir a função de tecnologia pedagógica, "ensinando" e instruindo seus leitores através de páginas recheadas de ilustrações, conselhos práticos, charadas, sonetos, crônicas e novelas. Com isso, as revistas inseriram-se de vez na paisagem urbana da capital, agora não mais influenciadas pelos gostos e clichês irradiados pela corte, mas inspiradas pelos ares republicanos e modernizantes impingidos por meio das reformas de Pereira Passos. Dentre os vários títulos que ganharam notoriedade nessa época encontram-se os nossos dois objetos de estudo, as revistas femininas Fon-Fon e Jornal das Moças.

A revista Fon-Fon foi publicada pela primeira vez em abril de 1907. Ostentando um título cuja alusão imediata é o barulho produzido pelas buzinas dos automóveis, a Fon-Fon se propunha a ser "um semanário alegre, político, crítico e esfuziante ${ }^{11 "}$, capaz de representar o espírito de modernidade que pairava sobre a capital da República. Em termos de tipologia documental, é possível caracterizá-la como um magazine destinado ao público feminino, com periodicidade semanal e que se autoproclamava "uma revista literária e ilustrada". De vida bastante longa, circulou de abril de 1907 a agosto de 1958. Seus idealizadores foram Mário Pederneiras, Gonzaga Duque e Lima Campos e sua sede estava

${ }^{11}$ Slogan veiculado pela revista Fon-Fon desde sua primeira edição. 
localizada na Rua da Assembleia, número 62 - hoje Rua República do Peru, 63 -, possuindo, ainda, sucursais em São Paulo, Londres e Paris.

Embora endereçada ao "belo sexo", é importante ressaltar que, em seus dois anos iniciais, Fon-Fon teve por referência o público masculino, haja vista a organização de seu conteúdo em seções como: Cabeça de Turco; Cova de cacos (onde se debatia um pouco de política); Moscas, além de comentários esportivos. Posteriormente, e visando ampliar seu nicho comercial, o semanário passou a priorizar o contato com o público feminino, guinada que se concretizou efetivamente na década de 1920, quando adquiriu feições típicas de "revista para mulheres". Aspecto que pôde ser constatado em nossas análises mediante identificação de um conjunto substancial de propagandas relacionadas a produtos femininos, mercadorias para o lar, roupas de mulheres, artigos de beleza, além de seções dedicadas a eventos sociais, conselhos de moda, beleza e educação infantil, dicas de cuidados domésticos, bem como comentários sobre teatro, cinema, bailes e salões.

Figura 1 - Anúncio da loja "A Notre-Dame de Paris"

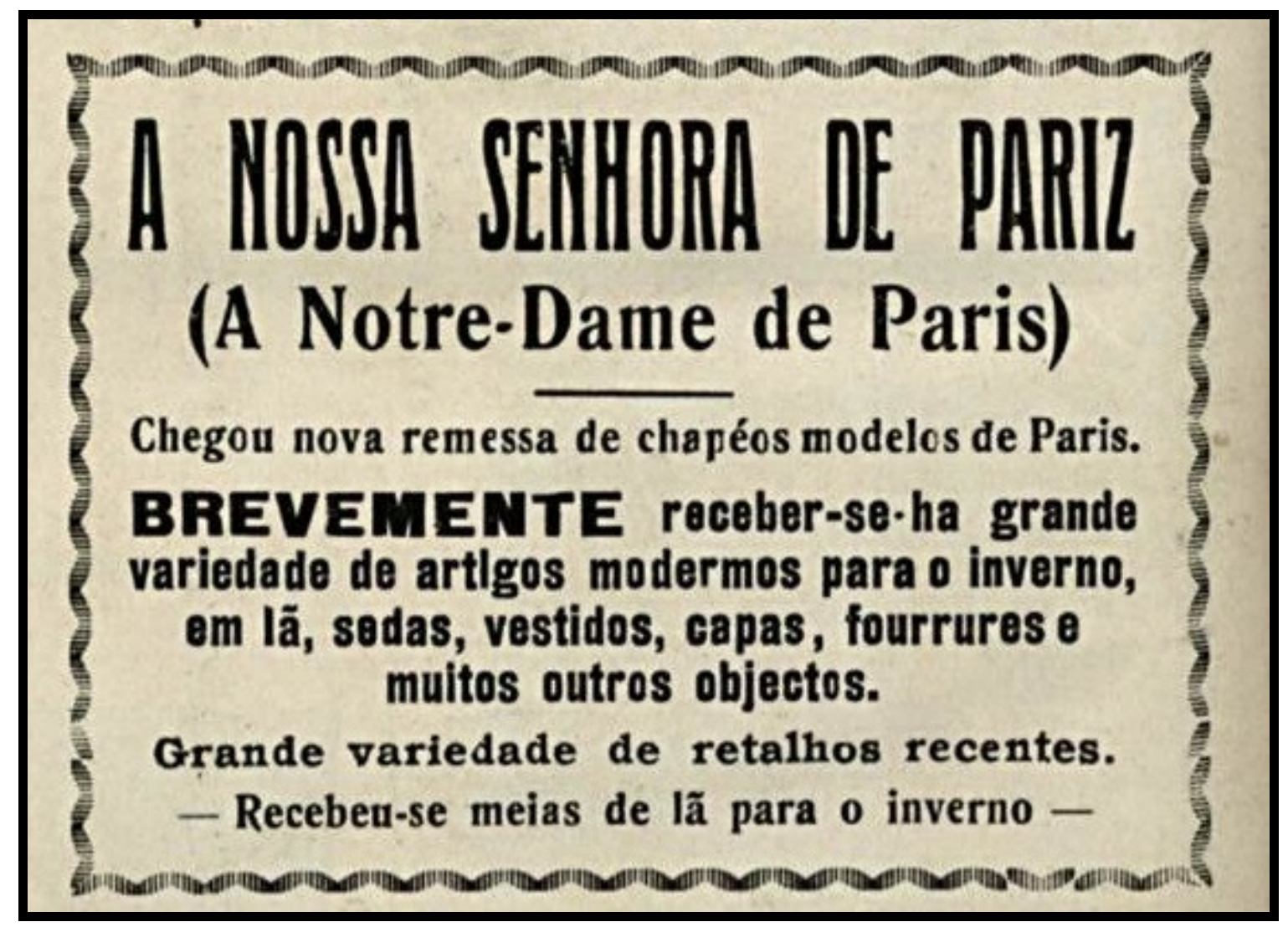

Fonte: FON-FON, n. 26, junho 1920. 
Figura 2 - Anúncio da Casa Raunier

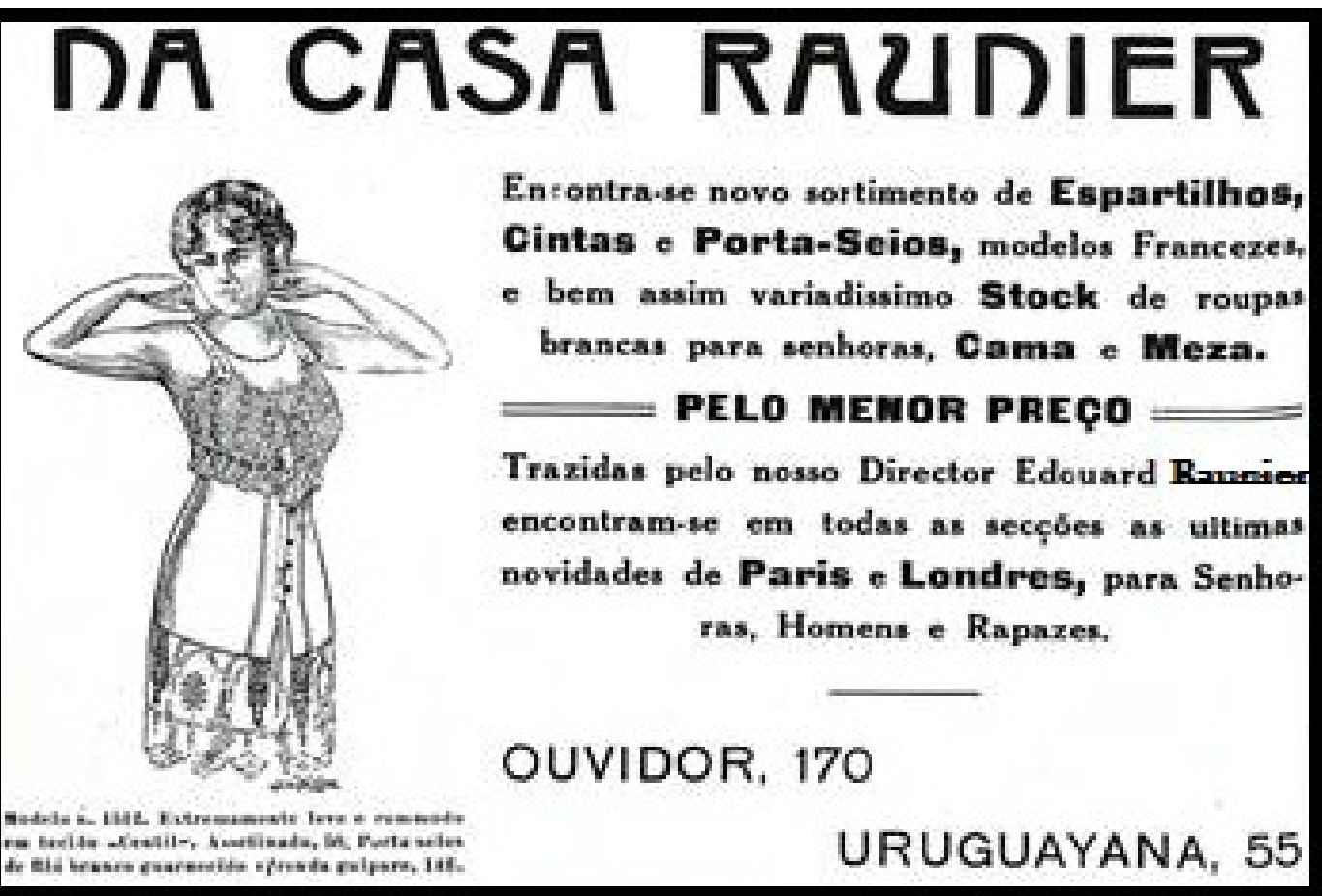

Fonte: Revista FON-FON, n. 4, janeiro, 1920.

Comercializada na capital a 400 réis $^{12}$ o exemplar avulso e a 500 réis nos demais estados da federação, a revista Fon-Fon insere-se na categoria de artigos consumidos pela elite, constatação reforçada pelas propagandas e eventos noticiados em suas páginas. Quanto a esse aspecto do periódico, Nahes afirma que:

[...] Possuidora de uma característica acentuadamente elitista, comum aos grandes magazines de informação da época, essa característica reside em sua natureza seletiva e temática, pois, mesmo sendo endereçada a um público variável e exclusivamente feminino, ou seja, burguesia e classe média, ela ainda estava impregnada pelo elitismo cultural que marca a imprensa do século XIX. (NAHES, 2007, p. 103-104).

Seguindo o modelo de muitos outros magazines do período entreguerras, o conteúdo veiculado em Fon-Fon caracterizava-se por sua superficialidade e mundanismo. À revista interessava mais apresentar semanalmente as últimas tendências da moda produzida em Paris e registrar a frivolidade da vida carioca através de charges e notas sociais, que transmitir informações relevantes ao desvelamento da situação econômica, política e cultural do país. Razão pela qual Nelson Werneck Sodré define a Fon-Fon como uma revista apolítica, centrada em reportar ao seu público a euforia da Belle Époque carioca. Nesse sentido, seu enfoque comunicacional eram os acontecimentos sociais e a representação

\footnotetext{
${ }^{12}$ Réis foi a unidade monetária brasileira de 1822 até 1942 , quando o Cruzeiro a substituiu.
} 
dos hábitos burgueses que tinham lugar na capital do país, como os foots realizados pelos cavalheiros e as recepções oferecidas por pomposas damas vestidas com as últimas modas vindas da França. Afirmativa endossada, por exemplo, pelo trecho que se segue:

Passam carros e mais carros, automoveis e mais automoveis em direção ao Corso, que coincide com o dia de S. João, dia de folga, permitindo a todos de participar do passeio em voga. Enquanto não sigo para lá também, attrahido pela festa anunciada no Pavilhão Mourisco e organizada por um grupo de distinctissimas senhoras da nossa elite, sento-me a uma das mesas da terrasse do Lopes Fernandes e mando vir uma saborosa mangaba, especialidade da acreditada casa. Ao lado do copo, figura meu inseparável carnet, confidente das minhas mais intimas impressões. N'elle rascunho os nomes das elegantes damas, dos smarts, de todos aquelles emfim que interessam á orientação jornalística do Fon-Fon, que se preza de ser uma revista mundana13. (FON-FON, seção "Na Calçada", n. 13, março 1928, grifos e destaques nossos.)

A fama editorial de Fon-Fon foi conseguida, pois, graças ao seu caráter polivalente. Expoente dos anseios de uma burguesia em ascensão, a revista prestava-se tanto ao jornalismo de variedades quanto à publicidade, aproximando-se de suas leitoras por meio de anúncios de produtos, serviços e eventos sociais. Suas páginas estavam permeadas de propagandas, as quais eram, em sua maioria, de mercadorias estrangeiras, posto serem esses os insumos considerados como os mais modernos e refinados. Com isso, é inegável que para as assinantes de Fon-Fon, o magazine exercia a função de guia comportamental e cartilha pedagógica. Dessa forma, analisando seu conteúdo, fazemos coro às afirmativas de Semiramis Nahes, para quem:

Fon-fon se transformou em uma cartilha político-educacional obrigatória, que deveria ser seguida incondicionalmente, oferecendo ao público feminino uma cultura de entretenimento, portanto, alienante, pouco questionadora, por meio de publicações como: receitas culinárias, bordados, propagandas, conselhos sobre qual a melhor postura feminina diante do homem (que conviesse a ele, logicamente), além de folhetins, americanos ou ingleses, focando suas lentes, sobremaneira, nas imagens. Moda, moldes e fotografia mencionavam, explicitamente, todas as regras do saber viver, do bom gosto, enfim, regras estas que todas as jovens de boa família deveriam conhecer, para realizar um bom casamento e ter um bom comportamento social. (NAHES, 2007, p. 107).

\footnotetext{
${ }^{13}$ Por se tratar de um estudo documental, optamos por manter a grafia original dos textos extraídos das revistas.
} 
Não por acaso a revista Fon-Fon firmou-se no cenário da Belle Epoque carioca, conquistando com seu jornalismo "leve", irônico e de entretenimento um espaço no universo simbólico feminino, chegando ao ponto de reorientar as práticas de leitura e os modos de interação com o impresso empreendidos por moças e senhoras da elite republicana. Trajetória semelhante à que foi traçada por nosso segundo objeto de estudo, o periódico Jornal das Moçar.

Circulando semanalmente tanto na cidade do Rio de Janeiro quanto nas principais capitais do país, o periódico Jornal das Moças era editado e publicado pela "Empreza Jornal das Moças, Menezes, Filho e C. Ltda.", cuja sede estava localizada na Avenida Rio Branco, número 180. Objetivando ser "a revista de maior penetração no lar"14, seu primeiro número veio à luz em 21 de maio de 1914, sendo extinta somente em 1965. No geral, cada novo exemplar - cuja edição saia sempre às quintasfeiras - possuía em média 60 páginas, confeccionadas em papel jornal, com dimensões aproximadas de uma folha A4. O miolo do texto era impresso em preto e branco, diferentemente das capas e contracapas que continham quase sempre ilustrações e/ou moldes de costura coloridos.

Assim como outras revistas ilustradas que circularam nos anos finais do século XIX e nas primeiras décadas de 1900, a Jornal das Moças inspirava-se nos grandes magazines de variedades impressos na Europa, sobretudo os francesas. Não sem razão, em seu primeiro número, o editorial já anunciava:

[As] varias revistas ilustradas, que têm surgido em nosso meio, em quase sua [ge]neralidade, ou constituem simples albuns de [ph]otographias e de modas ou revistas literárias, com acentuada feição mundana e humorística, nunca, porem, se preocupando como convém, com o cultivo de espirito de nossas gentis patrícias em outros ramos dos conhecimentos humanos. E' essa tarefa a que se impõe o Jornal das Moças. Cultivar, ilustrando, e ao mesmo tempo, deleitando o espirito encantador da mulher brasileira, a quem é dedicada esta revista, será o seu, sinão, único escopo, pelo menos a sua mais viva e mais ardente preoccupação. Levar ao lar das famílias patrícias, além da graça e do bom humor que empolgam, da musica e canto que embalam, os brincos e contos infantis que deleitam, a moda que agrada, do romance que desfaz as visões tristes da existência, da nota mundana que satisfaz a curiosidade insofrida, os conhecimentos uteis que instruem, eis certamente a mais bela feição da imprensa que procura viver do favor publico. Nesse nosso louvável objetivo, não temos poupado nem mediremos sacrifícios, razão por que acreditamos possa o Jornal das Moças agradar geralmente, visto como surge com esse único fim, attendendo antes á sua impeccavel feitura material que é de apurado gosto artistico, a começar pela sua capa. Esperamos a indispensavel preferencia de nossas gentis patricias para o exito completo do nosso emprehendimento. (JORNAL DAS MOÇAS, maio de 1914)

\footnotetext{
14 Slogan extraído da edição n.1975, ano de 1953.
} 
Com base nas prerrogativas inscritas nesse editorial, podemos inferir os assuntos tratados pelo Jornal das moças, bem como suas aspirações sociais. Desta feita, além de questões ligadas à moda, a revista veiculava em suas páginas conselhos domésticos, dicas de beleza, receitas culinárias, moldes de roupas, romances, partituras musicais, anedotas e notas sociais, todos dispostos em seções fixas, tais como: "Bilhetes Postaes", seção dedicada à publicação de correspondências dos leitores, com poesias, sonetos; assim como bilhetes que eram trocados entre amigas e casais; "Pelos Clubs" e "Pelos Salões", que traziam fotografias e notas de eventos sociais realizados em várias partes da capital carioca. Ao lado dessas, merece destaque o suplemento humorístico intitulado "A Palmatória", que se reportava, por meio de charges, anedotas e crônicas, à situação econômica e política da capital nacional e do Brasil como um todo. Sendo assim, e de maneira análoga à revista Fon-Fon, a Jornal das Moças constituía-se, para suas leitoras, em um grande manual de boas maneiras, mesmo que, por vezes, abordasse questões ligadas à atualidade da capital carioca e temas relevantes para apreensão da situação geral do país, como economia, cultura e política. 


\section{Figura 3 - Seção "Bilhetes Postaes", do Jornal das Moças}

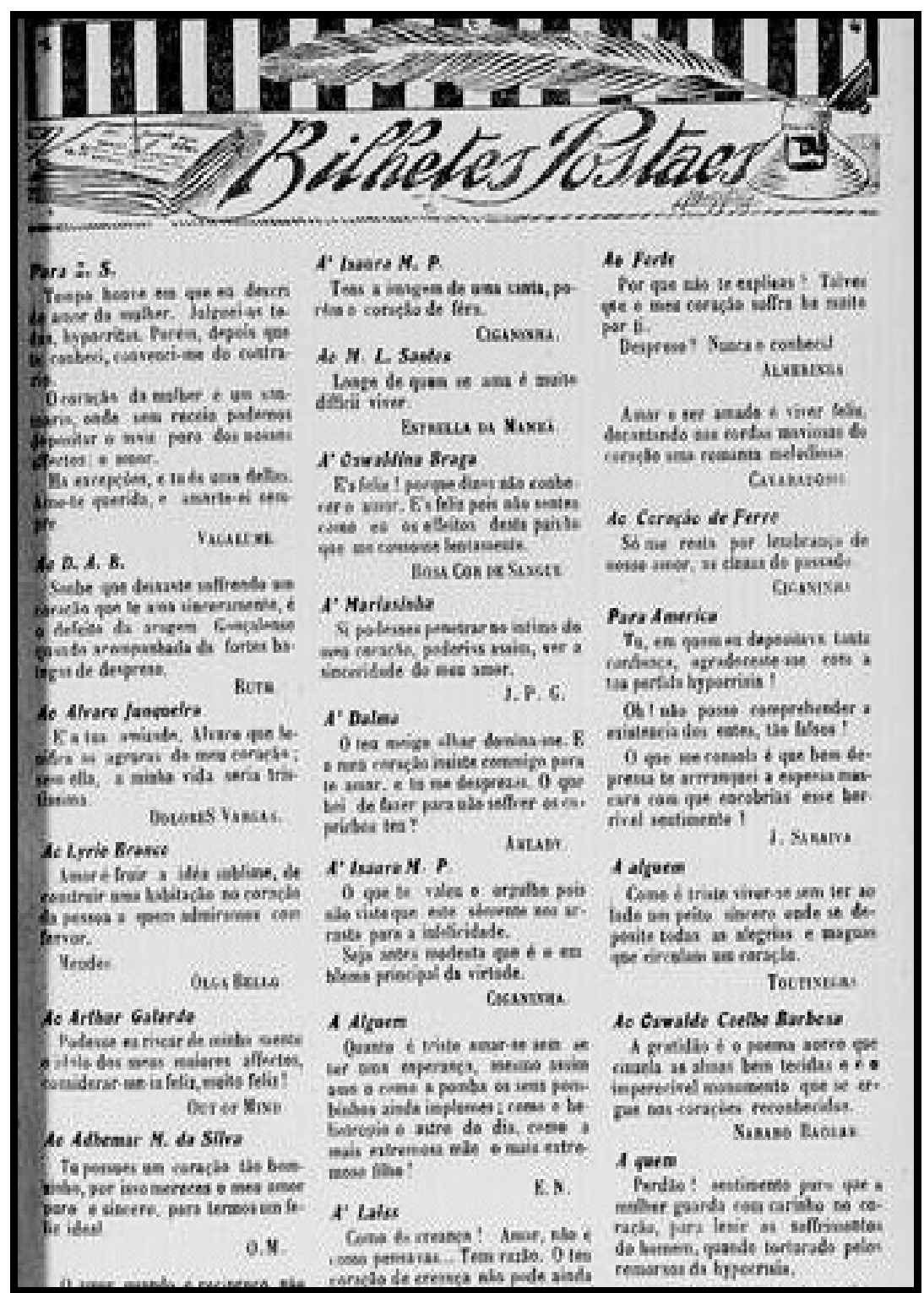

Fonte: JORNAL DAS MOÇAS, n. 238, janeiro 1920. 
Figura 4 - Suplemento humorístico "A Palmatória"

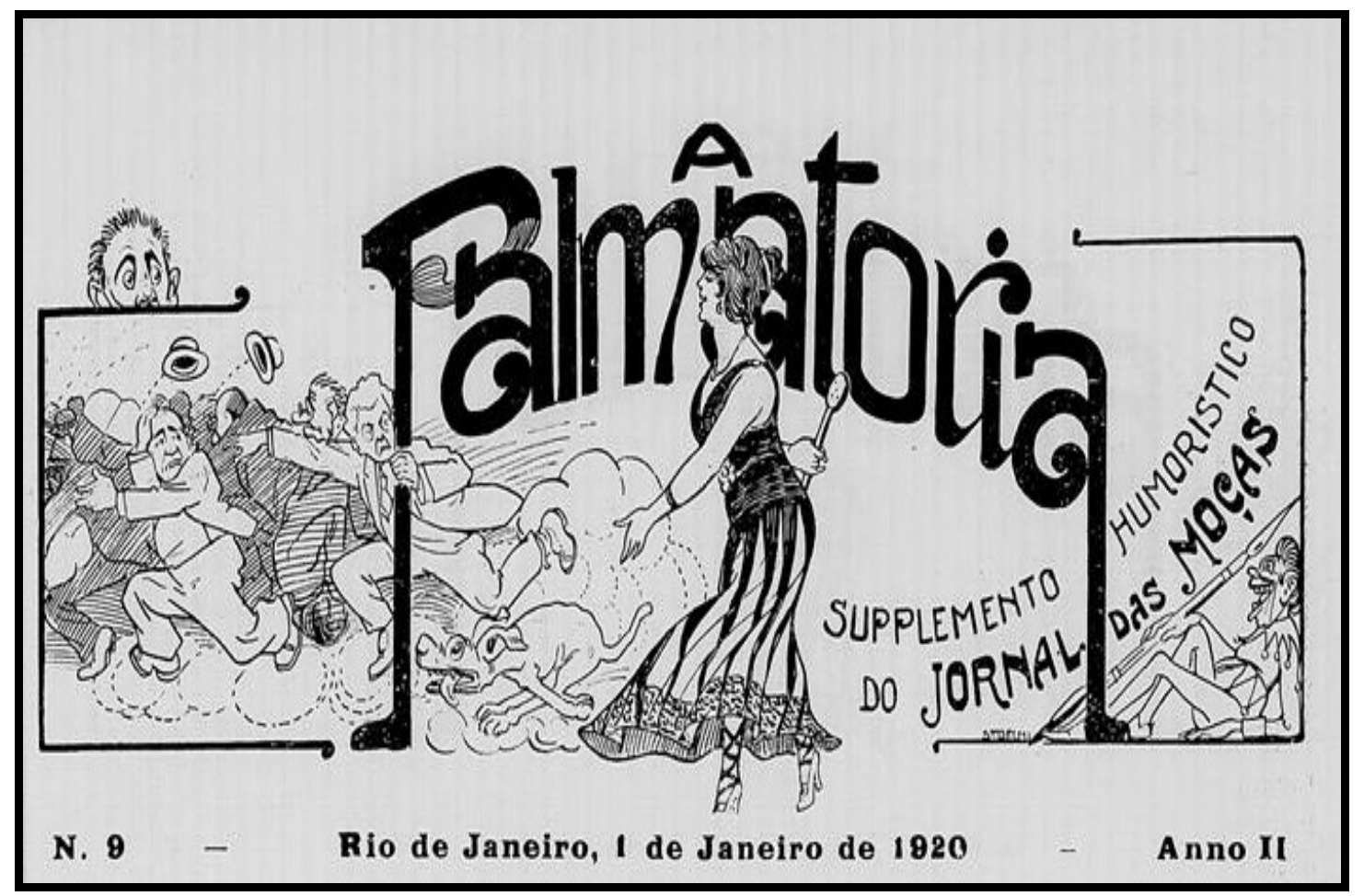

Fonte: JORNAL DAS MOÇAS, n. 237, janeiro 1920.

Condição que nos leva a concordar com Nelson Werneck Sodré e demarcarmos que as revistas femininas desse período - a década de 1920 -, definiam-se como grandes manuais de boa conduta, traçando modos de comportamento e disseminando padrões de consumo altamente descontextualizados da realidade das leitoras para as quais eram produzidas. São pois, nas palavras do pesquisador, periódicos superficiais e alienantes:

[...] a alienação, que era o traço dominante nessa literatura artificial, correspondia, no fim de contas, às condições materiais do país, e encontrava perfeita consonância na atividade política, limitada ao estreito círculo da "elite". Começava a surgir, no Rio, o antagonismo entre a "cidade" e o "subúrbio"; o chique era mesmo ignorar o Brasil e delirar por Paris. (SODRÉ, 1999, p. 300).

Além disso, e conforme lembrado por Almeida (2006, p. 126), embora o periódico Jornal das Moças se ocupasse de assuntos mundanos, domésticos e frívolos, não se deve desconsiderar que o mesmo alcançou um lugar de destaque no cenário da capital nacional porque divulgava informações e modos de conduta relacionados à vida das senhoras de nível social mais alto. Ou seja, era produzida e divulgada como um instrumento de distinção econômica, política e cultural.

Assim, conformava-se a mulher a mulher ao mercado do impresso, não apenas como leitora, mas, sobretudo, como consumidora de produtos 
de toda ordem, anunciados pela imprensa, através de publicações comprometidas com a venda e o lucro. [...] Nesse sentido, coube ao periodismo a prefiguração de modelos femininos, reiterando a tradicional postura de rainha do lar, mas abrindo um leque de condutas alternativas, em que se projetou a mulher emancipada, educadora, esportista, saudável, moderna e, por que não, a sufragista e feminina. Em outras palavras, prefigurava-se a mulher que interessava ao mercado, identificada como cliente em potencial, capaz de influenciar as decisões da família, vista como um ser em expansão. através do texto, mas subliminar e/ou ostensivamente pelo réclame e pela imagem a seu seviço, as mensagens daquele periodismo construíram-se consoante as exigências mercadológicas; privilegiaram a mulher, submetendo-a aos modelos de importação, aos valores de fora, ainda que se vivesse naqueles dias a euforia nacionalista, simultaneamente veiculadas pelo mesmo periodismo. (MARTINS, 2008, p. 378-379, grifos do autor).

Características gerais das quais não se furtam as duas revistas aqui em evidência. Sendo assim, e definidas as feições de nossos objetos e os modos como ambos refletem certos aspectos culturais da sociedade brasileira dos anos de 1920, cabe-nos, agora, lançarmos mais uma questão: em que medida todos esses apontamentos conferem visibilidade às práticas de leitura e de acesso à informação empreendidas tanto pelas leitoras de Fon-Fon quanto da revista Jornal das Moças? Responder essa pergunta implica conjugarmos duas estratégias metodológicas: pesquisa documental e análises vinculadas aos estudos de gênero, eis o que faremos abaixo.

\section{0 belo sexo e suas práticas de leitura: considerações a parti das revistas Fon-Fon e Jornal das moças}

Conforme exposto acima, a virada do século XIX para o XX fomentou o crescimento dos níveis de alfabetização no Rio de Janeiro, favorecendo a consolidação de novos grupos de leitores, inclusive o feminino. Impulsionadas pelo acesso à educação, as mulheres logo se apropriaram do universo das letras e das práticas de leitura. Nesse sentido, os magazines tiveram um papel importante na formação de moças e senhoras da Belle Epoque carioca, posto oferecerem em suas páginas, além de material recreativo, conselhos de ordem prática, romances folhetins, notas sobre a vida mundana, poemas e crônicas de cunho político-social, como é o caso tanto da revista Fon-Fon, quanto da Jornal das moças.

Periódicos que tinham como leitoras mulheres com um poder aquisitivo razoável, já que o preço médio de cada exemplar das revistas encontrava-se na faixa de 500 réis. Comparando-se esse valor com o salário médio de um soldado do Exército Brasileiro, $12 \$ 000$ réis ${ }^{15}$ mensais, cada exemplar correspondia a $4 \%$ desse montante. Outro fator que

${ }^{15}$ Valor extraído de uma reportagem publicada no JORNAL DAS MOÇAS, n. 249, mar. 1920, p. 22, sobre o aumento concedido aos militares naquele mesmo ano. 
reforça tal inferência são os anúncios de bens de consumo veiculados nas páginas dessas revistas. Para adquiri-los, fazia-se necessário possuir certa condição financeira, já que a maioria dos produtos eram importados. Vejamos um exemplo:

Figura 5 - Anúncio da Perfumaria Avenida

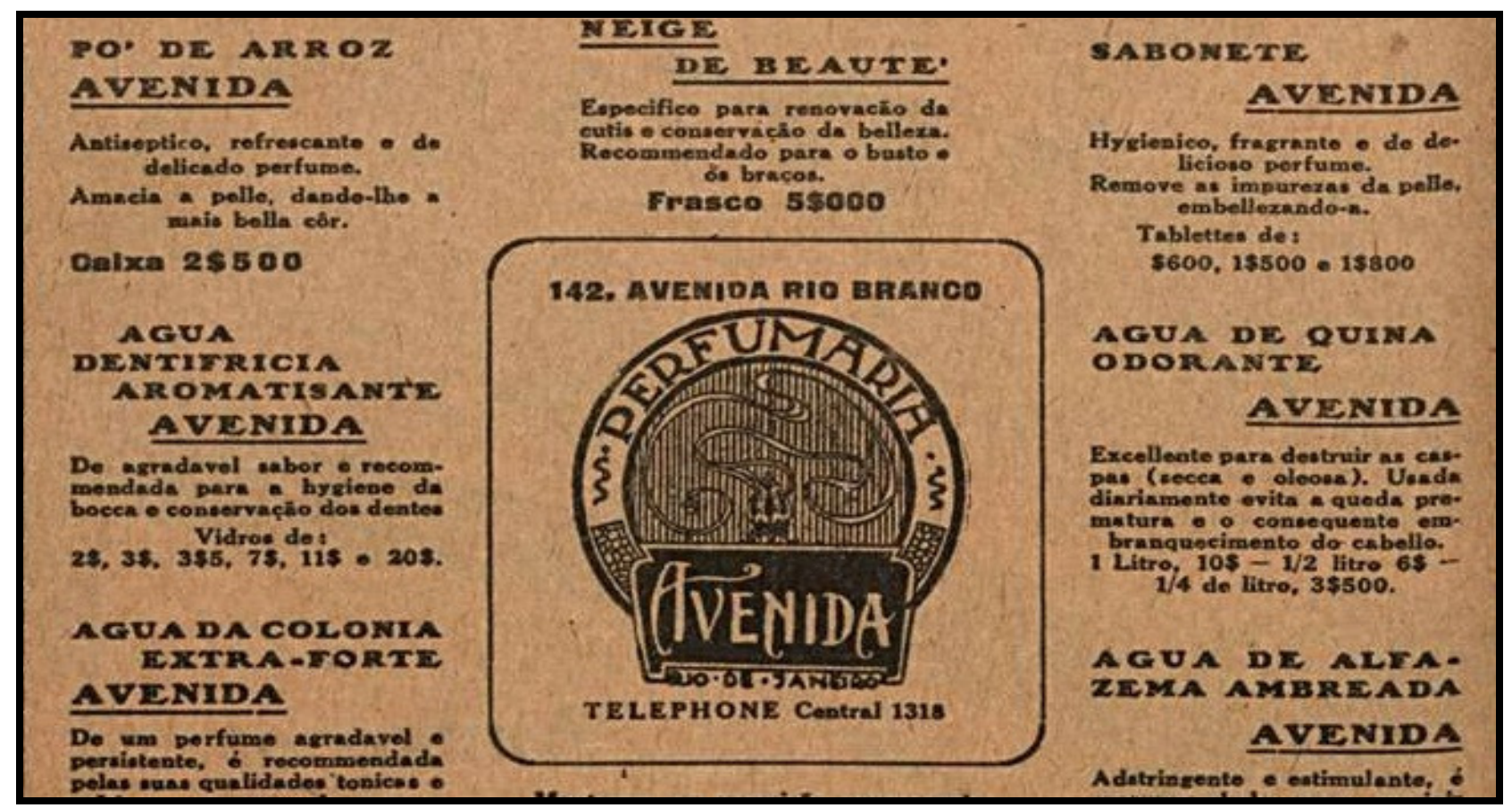

Fonte: FON-FON, n. 4, jan. 1920.

Tendência também observada por Nahes (2007, p. 104) e Nukácia de Almeida (2006, p. 7), cujos estudos indicam que as duas revistas eram endereçadas a um público de faixa etária variável, mas de duas camadas sociais bem determinadas: mulheres de classe alta e média. Considerações endossadas pelos conteúdos de algumas seções da Fon-Fon e da Jornal das Moças, onde são recorrentes o uso de uma linguagem mais rebuscada e a presença de textos em outros idiomas, especialmente o francês, conforme reforçado pelo exemplo abaixo 
Figura 6 - Seção Souvenirs do Jornal das Moças

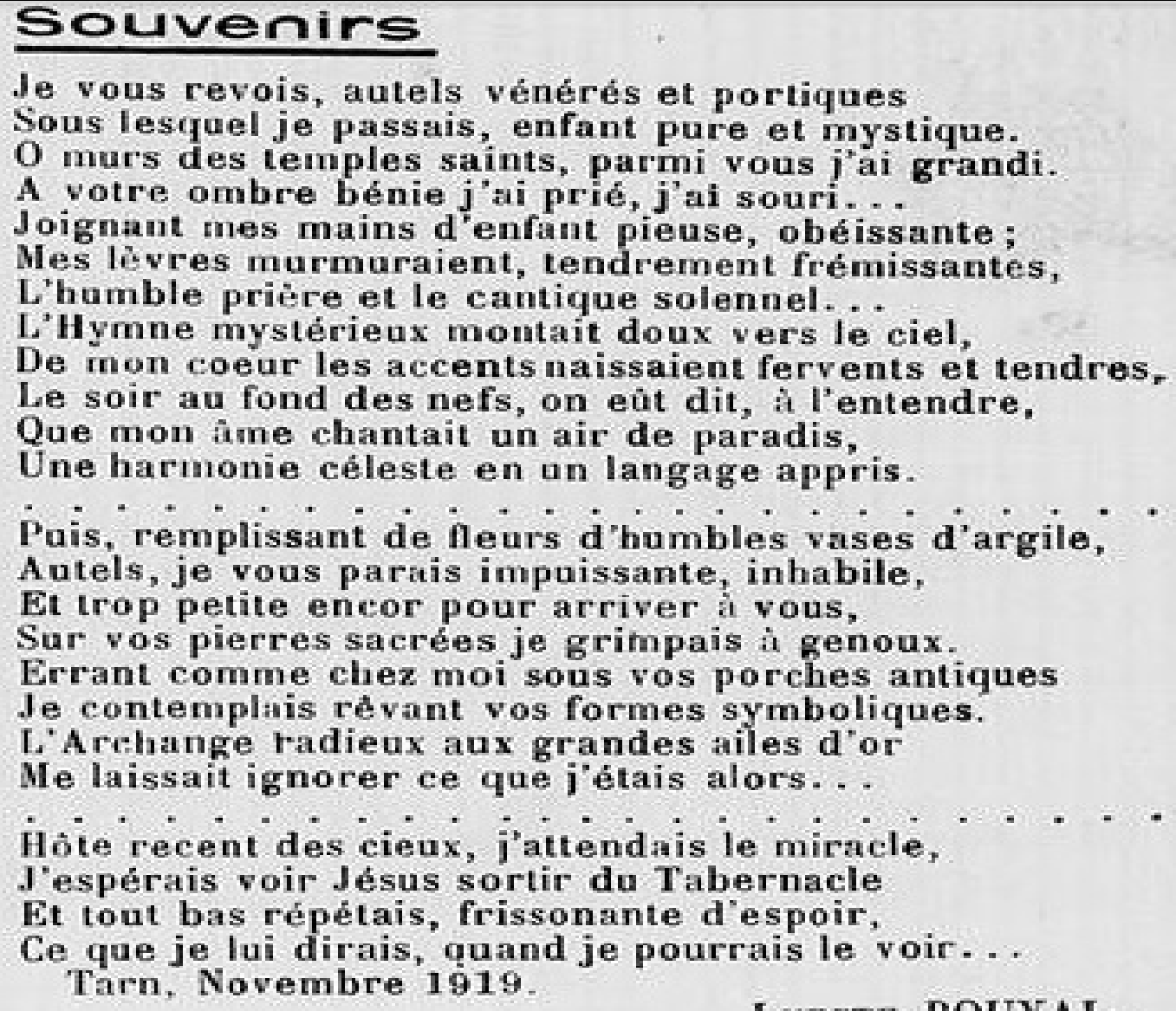

Fonte: JORNAL DAS MOÇAS, n. 250, 1920

Mesmo sendo caracterizada como uma leitura amena e frívola, não é possível afirmar que as leitoras dessas revistas se encontravam totalmente alheias aos fatos políticos e econômicos em voga no cenário nacional e internacional. Contudo, faz-se necessário mencionar que, em ambos os periódicos, esses temas eram abordados quase sempre de forma sutil e superficial. No caso de Fon-Fon, encontramos as seções "Perfis Internacionaes" e "Memórias da Guerra" que apresentavam notícias sobre fatos ocorridos ao redor do mundo e assuntos políticos pós Primeira Guerra Mundial. Já no Jornal das Moças, merece destaque a seção "A Palmatória", espaço onde eram publicadas charges sobre acontecimentos políticos da época. Há, ainda, no caso desse último, a seção "De tudo um pouco", na qual eram subscritas notas sobre diversos assuntos, especialmente sobre o panorama socioeconômico vivenciado pelo Brasil e sua correlação com aquilo que acontecia no Mundo.

Com isso, e não nos esquecendo que foi somente a partir dos anos iniciais do século $X X$ que as mulheres brasileiras começaram a ter uma formação educacional próxima à que era oferecida aos seus pais, maridos e irmãos, a importância das revistas femininas enquanto agentes mobilizadores desse processo instrucional não deve ser menosprezada. Nesses termos, mesmo categorizando a imprensa feminina como 
"jornalismo de futilidades", tais revistas desencadearam um processo de socialização das mulheres que tinha a leitura como prática de referência. Visando-se comprovar esse argumento, dispomos abaixo alguns excertos extraídos das duas revistas que servem como sinalizadores de certos hábitos e práticas de leitura empreendidas pelas assinantes de Fon-Fon e da Jornal das Moças ao longo da década de 1920.

O primeiro deles foi transcrito da edição de fevereiro de 1920 da Jornal das Moças. Trata-se de um anúncio indicando que o folhetim "Magdalena" seria publicado em formato de livro pela revista, afim de que fosse colecionado e encadernado por suas leitoras. Eis a chamada na íntegra:

No dia 26 do corrente, começaremos a publicar o romance MAGDALENA em folhetim, afim de ser colecionado e encadernado pelas nossas leitoras. MAGDALENA é o título de um belo e sentimental romance, cheio de lances empolgantes, escrito especialmente para a revista "Jornal das Moças", pela querida e talentosa escritora patrícia Alice de Almeida, e ilustrado com inúmeras gravuras de $A$. Kreisler, que preparou uma bela capa a três cores, que será publicada no fim do romance. (JORNAL DAS MOÇAS, fevereiro 1920).

Por sua vez, a revista Fon-Fon notifica, na edição de setembro de 1921, a aguardada publicação do romance francês "Muito tarde", de Ponson de Terrail: "Brevemente, em folhetim, o grande romance do conhecido escrito francês Ponson de Terrail: Muito tarde! Com inúmeras ilustrações". Contudo, embora os romances fossem os textos literários de maior abundância, há também seções dedicadas à publicação de poemas e sonetos, alguns deles enviados pelas próprias assinantes de ambas as revistas, conforme atesta a composição abaixo.

Figura 7 - Poesia "Borboletas" da leitora Aristotelina Leite Camargos

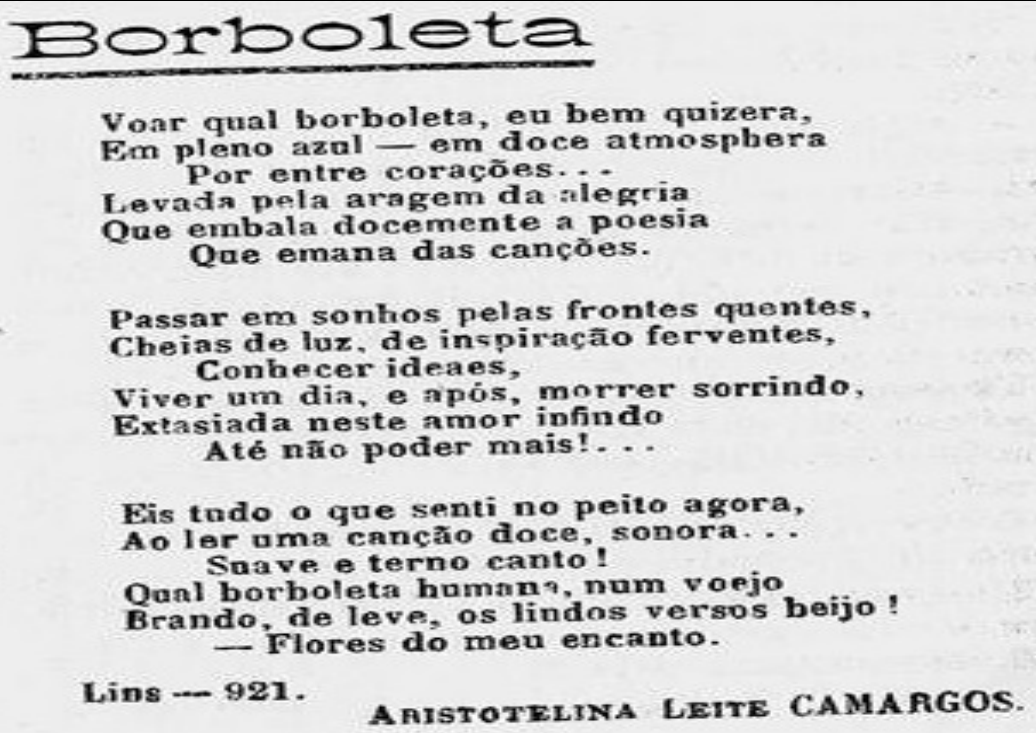

Fonte: JORNAL DAS MOÇAS, n. 346, 1922. 
Por sua vez, a crônica, mesmo que de maneira menos recorrente, também possuía espaço nesses periódicos. A seção "Petropolitanas" de Fon-Fon caracterizava-se por apresentar pequenas crônicas sobre o diadia da cidade e dos hábitos da elite carioca. Já na Jornal das Moças, a seção "Chronica" cumpria a mesma função daquela presente em sua concorrente.

Figura 8 - Seção "Petropolitanas" de Fon-Fon

PETROPOLITANAS A ambição de muitas familias é ter um cosinheiro chinez. Pois aconselho ás que tiveı em tal desejo, não o satisfazerem. Hontem, conservando na venida Piabanha com um illustre magistrado, elle me contou uma horrivel historia de cosinheiro chinez.

Vou narral-a para que ninguem acceite em sua casa esse typo criminnso.

A despeza de sua casa, no mercado, diariamente, disse me ello, ascendia a trinta mil reis; mas, depois que sua esposa arranjára um mestre cuco do Celeste Imperio, fôra reduzida a nove mil e quinhento:, dez mil reis. Un prodigio. Um remedio contra a carestia. E eram os melhores acepipes ao almoço e ao jantar : legumes tenros, frangos saborosos, perús admiraveis. A familia toda até engordava.

Um dia elle nao se contivera, seguira o cosinheiro ao mercado, espionando 0 de longe, pare saber como conseguia aquelle milagre. Vira, horrorisado, o celestial, apanhar repo. lhos e nabiças no lixo dos quitandeiros, aproveitando os oue ainda se podiam comer. Vira.o comprar por dez reis de mel coado frangos e perús, doentes ou mortos de vespera. Estes eram os melhores, já estavam naturaimente faisandé s... 0 chim ainda ganhava a metade da' despezas...

Excusado será dizer que o cozinheiro nesse dia năo lhe entrou mais em casa. $\mathrm{E}$ as senhoras donas de casi, depois deste exemplo, ainda quererão cozinheircs chinezes ?...

Fonte: FON-FON, jan. 1920.

Para além dessas tipologias textuais e evocando o que já foi dito anteriormente, era comum que tais revistas fossem vendidas como "cartilhas pedagógicas", proposição que ganha corpo nas seções de "conselho" presentes em cada uma delas. No geral, tais conselhos versavam sobre etiqueta, dicas de beleza, higiene e de comportamento social, indicando, pois, uma preocupação com o fomento de leituras reconhecidamente "civilizatórias" e "moralizantes". O excerto a seguir, que circulou na revista Jornal das Moças em junho de 1922, constitui-se em bom exemplo disso que acabamos de afirmar:

\section{MULHERES}

Mulheres! Se a natureza não vos conceder a ventura de ser mães, não blasfemeis. [...] Ser mãe não é somente estorcer-se nas supremas convulsões e dar a vida a um ser; ser mãe, é ter nos lábios um sorriso para cada amargura, ser mãe, é amar as criancinhas formosas, amparar o órfão, é aconselhar a juventude inconsciente [...]. (JORNAL DAS MOÇAS, junho de 1922).

A recorrência dessa tipologia textual, somada ao conjunto de propagandas veiculadas nas páginas das revistas Fon-Fon e Jornal das Moças nos impele a chamarmos atenção para um perfil de leitora que se mostra inscrita nas classes média e alta da sociedade carioca, que se tornavam assinantes dos dois magazines basicamente em função de três justificativas: as possibilidades de entretenimento oferecidas pelos periódicos; a distinção social suscitada pelo acesso a eles, aos produtos divulgados em suas páginas e as informações por eles disseminadas; e, é claro, a inserção em um espaço de sociabilidade feminina pautado por modos de comportamentos, regras de etiquetas e formas de viver o 
urbano que se faziam melhor apreendidas através da leitura recorrente de ambas as revistas. Portanto, não há como deixar de notar que:

Ao fim e ao cabo, o que resultou desse periodismo consumido por mulheres e disseminador de comportamentos foi a veiculação de duas imagens de mulher. Uma do texto e outra da publicidade. Texto ainda construído para a mãe-esposa, conformando a imagem da mulher brasileira aos costumes e tradições, de forte influência católica, de apelo nacionalista; já as imagens, as ilustrações, a publicidade com vistas ao consumo, configuravam o modelo de fora, da mulher esportista, liberada, moderna, que fumava e dirigia automóveis, engendrando o estereótipo que reinou naquela transição: a melindrosa.[...] Em outras palavras, rainha do lar no texto, no espaço da privacidade e moderna e liberada na propaganda, colocando-se no espaço público. (MARTINS, 2008, p. 385, grifos do autor).

Sendo assim, entendemos que as informações difundidas e as estratégias comunicacionais empreendidas tanto por Fon-Fon quanto pela revista Jornal das Moças se postam como espelho de uma sociedade que, embora ampliando a participação das mulheres em vários de seus segmentos e estruturas, não era capaz de desvincular esse contingente populacional da presença e do julgo masculino. Razão pela qual ofereciam textos de fácil compreensão e tidos como literatura de amenidades, cuja contato permanente, além de ser incentivado, tinha por objetivo converter suas leitoras em boas mulheres, donas de casas prendadas, mães dedicadas e esposas afetuosas. Traçamos mais alguns apontamentos a este respeito nas considerações finais que se seguem.

\section{Considerações finais}

Tendo por referência o contexto histórico-cultural aqui abordado, é possível salientarmos que, entre os anos finais do século XIX e as primeiras décadas de 1900, o lugar social destinado às mulheres transformou-se sobremaneira. Isso porque, o rápido desenvolvimento econômico e urbanístico que alterou o ritmo de vida das principais cidades do país, também imprimiu novos padrões de comportamento para o público feminino, o qual deixou de ser figura coadjuvante no âmbito das relações conjugais para assumir responsabilidades cada vez maiores em relação à administração da casa e à educação dos filhos. Desta forma, ainda que de modo discreto, meninas, moças e senhoras começaram a se apropriarem dos espaços públicos e a serem "educadas" formalmente, mesmo que estas instâncias reforçassem, na prática e no discurso, a dominação masculina.

Contudo, embora tais mudanças tenham atingindo um amplo espectro geográfico, é preciso demarcar que elas foram vivenciadas de modo mais intenso pelas classes dominantes, visto que as mulheres de 
baixa renda não possuíam acesso à educação, mesmo assumindo postos de trabalho informal com vistas a complementar a renda familiar. Com isso, é premente observar que esses novos enquadramentos facultaram às mulheres a condição de se desvencilharem da representação de sexo frágil, saírem de suas casas e ganharem as ruas. Não sem razão, dados do Recenseamento Geral do Brasil emitidos nos anos de 1890, 1906 e 1920 apontam uma considerável elevação no percentual de mulheres alfabetizadas em relação aos demais contingentes populacionais do país. Em 1890 os índices de alfabetização feminina se encontravam na marca de 43,53\%; em 1906 passaram a 46,01\%; e em 1920 alcançaram a cifra de $55,77 \%$.

Todavia, a escolarização, mesmo nas camadas mais abastadas da sociedade, não era o caminho mais utilizado para se alcançar avanços intelectuais por parte das mulheres. A leitura praticada no espaço doméstico muitas vezes supria a falta de uma educação formalizada. Praticadas individualmente ou em grupos fechados, essas leituras serviam tanto à função pedagógica quanto à de lazer, visto que em tais encontros liam-se especialmente materiais ditos como "saudáveis", a saber: romances, sonetos, poesias e revistas femininas.

Foi, pois, nesses espaços de intimidade e sociabilidade que revistas como a Fon-Fon e a Jornal das Moças alcançaram sua fama e se popularizaram. Servindo a um só tempo às funções de lazer, instrução pedagógica e material informacional, tanto uma quanto a outra impulsionaram a formação intelectual de inúmeras mulheres, bem como sua inserção no mundo das letras.

Escolarizada, atenta às modas e figurinos de seu tempo, a leitora encontrou nas revistas outra alternativa de consumo do impresso. Não aquele da leitura compenetrada, dependente de obediência própria, de autor consagrado, da dificultosa aquisição do livro. Mas, da leitura folhetinesca, em pedaços quase aleatória, conduzida pela variedade de seções e ilustrações, que ao fim e ao cabo, definiu dois códigos de consumo do impresso: aquele do texto e o outro, da imagem. (MARTINS, 2008, p. 377-378).

Desta feita, circulando por longo período, o sucesso comercial dos dois magazines não se mostra atrelado apenas às inovações editoriais postas em circulação à cada ano, mais que isso, chamou-nos a atenção a capacidade que essas revistas tinham de se adaptarem aos interesses e necessidades informacionais/comunicacionais de suas leitoras. Por isso, se por um lado tais periódicos influenciavam nas leituras de suas assinantes, por outro eram por elas influenciados, apresentando em suas páginas textos que buscavam suprir as demandas de um público em formação e com grandes potencialidades de inserção e projeção social.

Portanto, e foi isso que esse trabalho objetivou demonstrar, não há como desconsiderarmos a riqueza desses materiais para as análises que buscam apreender, inclusive nos campos da Biblioteconomia e da Ciência 
da Informação, como as práticas informacionais e os gestos leitores instituem-se e se desenvolvem em tempos e espaços específicos, assim como certos públicos de usuários, no caso aqui as mulheres cariocas da década de 1920, se relacionavam com o universo social, político, econômico, cultural e informacional no qual estavam inscritos.

\section{Referências}

ALMEIDA, N. M. A. de. Revistas femininas e educação da mulher: o Jornal das Moças. Fortaleza: Universidade Estadual do Ceará, 2006. Disponível em:

<http://alb.com.br/arquivomorto/edicoes_anteriores/anais16/sem03pdf/s m03ss14_06.pdf>. Acesso em: 8 jan. 2014.

ARAÚJO, R. M. B.a de. A vocação do prazer: a cidade e a família no Rio de Janeiro republicano. Rio de Janeiro: Rocco, 1995.

BESSONE, T. As leitoras no Rio de Janeiro do século XIX: a difusão da literatura. Gênero, v. 5, n. 2, p. 81-93, 10 sem. 2005.

BONVOISIN, S.-M.; MAIGNIEN, M. La presse féminine. Paris: Presses Universitaires de France, 1986.

BUITONI, D. S. Imprensa feminina. São Paulo: Ática, 1990.

BUITONI, D. S. Mulher de papel: a representação da mulher pela imprensa feminina brasileira. 2. ed. São Paulo: Sumus Editorial, 2009.

CARVALHO, K. de. A imprensa feminina no Rio de Janeiro, anos 20: um sistema de informação cultural. Ciência da Informação, Brasília, DF, v. 24, n. 1, p. 1-11, 1995.

CAVAlLO, G.; CHARTIER, R. (Orgs.). História da leitura no mundo ocidental. São Paulo: Ática, 1999. 2 v.

CELLARD, A. A análise documental. In: POUPART, J. [Org.]. A pesquisa qualitativa: enfoques epistemológicos e metodológicos. Petrópolis: Vozes, 2008. p. 295-316.

DIÁRIO DE PERNAMBUCO. Pernambuco: Typografia Fidedigna, 18251984.

FON-FON: semanário alegre, político, crítico e esfusiante. Rio de Janeiro: Fon-Fon, 1907-1958. Semanal.

FUJITA, M. S. L. A leitura documentária na perspectiva de suas variáveis: leitor-texto-contexto. DataGramaZero, v. 5, n .4, p. 1-26, ago. 2004.

JORNAL DAS MOÇAS. Rio de Janeiro: Empreza Jornal das Moças, Menezes, Filho e C. Ltda. 1914-1965. Semanal.

LEITE, M. M. A condição feminina no Rio de Janeiro: século XIX. São Paulo: Hucitec, 1984.

MACENA, F. F. Madames, mademoiselles, melindrosas: "feminino" e modernidade na revista Fon-Fon!. 2010. 128 f. Dissertação (Mestrado em 
História) - Programa de Pós-Graduação em História, Universidade de Brasília, Brasília, 2010.

MARTINS, A. L. Revistas em revista: imprensa e práticas culturais em tempos de República, São Paulo (1890-1922). São Paulo: Edusp; Fapesp, 2008.

MORAIS, Maria A. C. de. Leituras femininas no século XIX: (1850-1900). 1996. 197f. Tese (Doutorado em Educação) - Faculdade de Educação, Universidade Estadual de Campinas, Campinas, 1996.

NAHES, S. Revista Fon-Fon: a imagem da mulher no Estado Novo (19371945). São Paulo: Arte \& Ciência, 2007.

OLIVEIRA, Cláudia de; VELLOSO, Mônica P.; LINS, Vera. O moderno em revistas: representações do Rio de Janeiro de 1890 a 1930 . Rio de Janeiro: Garamond, 2010.

ORTIZ, R. Cultura e modernidade: a França no século XIX. São Paulo: Brasiliense, 1991.

SANTOS, L. P. B. dos. "A viga mestra" da educação feminina: O Jornal das moças e seu caráter formativo nos anos 1950. In: SEMANA DE EDUCAÇÂO, 2008, Rio de Janeiro. Trabalhos... Rio de Janeiro: Universidade do Estado do Rio de Janeiro, 2008.

SCALZO, M. Jornalismo de revista. 4. ed. rev. e atual. São Paulo: Contexto, 2003.

SCOTT, A. S. O caleidoscópio dos arranjos familiares. In: PINSKY, C. B.; PEDRO, J. M. Nova história das mulheres no Brasil. São Paulo: Contexto, 2012. p. $15-42$.

SODRÉ, N. W. História da imprensa no Brasil. 4. ed. atual. Rio de Janeiro: Mauad, 1999.

ZANON, M. C. Fon-Fon!: um registro da vida mundana no Rio de Janeiro da Belle Époque. Patrimônio e Memória, v. 1, n. 2, p.18-30, 2005. 